\title{
Susceptibility of Three Muskmelon Cucumis melo L. Cultivars to Infestation with Tetranychus urticae Koch
}

\author{
A. K. Aiad*; E.M.A. El-Saiedy ${ }^{* *}$ and Aml H.M Romeih ${ }^{* * *}$ \\ * Plant Protection Research Institute, Agriculture Research Center, Dokki, Giza, Egypt \\ ${ }^{* *}$ Plant Protection Dep., National Research Center, Dokki, Giza, Egypt \\ **** Dept. of Zoology and Agric. Nematology, Fac. of Agric., Cairo Univ., Giza, Egypt.
}

\begin{abstract}
Experiments were conducted to evaluate the susceptibility of three muskmelon cultivars (Ananas France, Galia2 and Shahd2) to infestation with Tetranychus urticae Koch and its population fluctuation during two successive seasons (2012 and 2013) at Behira governorate. Galia2 cultivar was the most highly susceptible recording average of 97.16 and 100.3 mite moving stages and 86.38 and 74.20 eggs/leaf during the two successive seasons, respectively followed by Shahd2 cultivar recording 86.16 and 86.43 mite individuals during the two seasons, respectively. The lowest infestation was recorded on ananas france registering 41 and 39.40 ' during the two successive seasons respectively. Susceptibility of muskmelon cultivars to infestation with $T$. urticae may be affected by its chemical contents. Negative relationship occurring between motile mite infestation levels and total Alkloids; while no correlation for eggs with all components. Mite population reached its peak during April in the two successive seasons.
\end{abstract}

Key Words: Tetranychus urticae, Muskmelon cultivars.

\section{INTRODUCTION}

Musk melon Cucumis melo L. (Family Cucurbitaceae) is considered one of the most important vegetable crops in Egypt. It is a species of melons that has been developed into many cultivated varieties. It is also a variety more closely resemble of watermelon which usually infested with Tetranychus urticae Koch (Farrag et al., 1984) and the tarsonemid mite Polyphagotarsonemus latus Banks (Kousik et al., 2007).Evaluation the susceptibility of some musk melon cultivars to infestation with $T$. urticae is considered important to select the more resistant ones and to avoid using pesticides.

Chemical contents which normally vary from variety to another, may affect the population level of herbivores. Abdallah et al. (2009) studied the host plant resistant to $T$. urticae. Thus, the present work was conducted to evaluate the susceptibility of three muskmelon cultivars with Tetranychus urticae infestation and its correlation with certain leaf chemical contents. The population dynamics of the mite was also studied throughout the two successive seasons 2012 and 2013.

\section{MATERIALS AND METHODS}

This investigation was carried out in Behara governorate at Nobaria distrect. Three muskmelon cultivars Ananas France, Galia 2 and Shahd 2 were cultivated in open field during the two successive seasons (summer season 2012 and early summer season 2013 in an area about twenty faddan. The population dynamics of T. urticae Koch infesting the three previous cultivars. The first season began from $15^{\text {th }}$ Jan 2012 up to $23^{\text {rd }}$ Feb.2012; while second season began from $14^{\text {th }}$ Jan 2013 up to $24^{\text {th }}$ Feb.2013.Samples each of 20 leaves were weekly collected from every muskmelon cultivar and examined for movable stages and the eggs of $T$. urticae occurrence. Total amino acids and free amino acids were determined according to Etsushiro et al. (1981) method; total phenols content according to Folin-Ciocalteu, described by Meda et al. (2005); total Alkoloids titermetrically according to Sabri et al. (1973). Total carotenes were determined colormetrically according to Holden (1965), Tannins by using Vanillin hydrochloric acid method according to Burn (1971).Chemical analysis was carried out in the growing season of the three previous cultivars during the two periods peak of infestation. Muskmelon leaves were collected, transferred to laboratory and dried at room temperature and relative humidity then transferred to the laboratory of the Faculty of Agriculture Research Park, Cairo Univ. for chemical analysis.

\section{RESULTS AND DISCUSSION}

Data in table (1) demonstrate that the susceptibility of three previous muskmelon cultivars to the movable stages of $T$. urticae infestation during season 2012 could be arranged descendingly as follows: Galia 2 and Shahd 2 (42\% and 36\%) followed by Ananas France which was moderately infested 
Table (1): Susceptibility of three cultivars to Tetranychus urticae infestation during 2012 and 2013 seasons

\begin{tabular}{lcccc}
\hline \multicolumn{4}{c}{ Mean number of T. urticae movable stages/leaf } \\
\hline & summer season 2012 & \multicolumn{2}{c}{ Early summer season 2013 } \\
\hline \multicolumn{1}{c}{ Muskmelon cultvar } & Mean number & \%infestation & Mean number & \%infestation \\
\hline Galia 2 & $48.2 \pm 29.5^{\mathrm{a}}$ & $42 \%$ & $53.4 \pm 31^{\mathrm{a}}$ & $44.5 \%$ \\
\hline Shahd 2 & $42.3 \pm 27.8^{\mathrm{a}}$ & $36 \%$ & $41.4 \pm 24^{\mathrm{b}}$ & $20.7 \%$ \\
\hline Ananas France & $24.2 \pm 11.3^{\mathrm{b}}$ & $21.1 \%$ & $24.8 \pm 10.9^{\mathrm{c}}$ & $34.8 \%$ \\
\hline LSD value at 0.05 & 8.4 & & 8.5 & \\
\hline
\end{tabular}

Means with same letter are not significantly different

Table(2): Susceptibility of three cultivars to eggs of Tetranychus urticae infestation during 2012 and 2013 seasons

\begin{tabular}{lcccc}
\hline \multicolumn{3}{c}{ Mean number of T. urticae eggs/leaf } \\
\hline \multicolumn{1}{c}{ Muskmelon cultvar } & Mean number & \%infestation & Mean number & \%arly summer season 2013 \\
\hline Galia 2 & $46.7^{\mathrm{a}} \pm 24.5$ & $43.4 \%$ & $50^{\mathrm{a}} \pm 24.4$ & $42.9 \%$ \\
\hline Shahd 2 & $36.5^{\mathrm{b}} \pm 21.4$ & $33.9 \%$ & $41.4^{\mathrm{b}} \pm 22.9$ & $35.4 \%$ \\
\hline Ananas France & $24.4^{\mathrm{c}} \pm 12.4$ & $22.7 \%$ & $25.4^{\mathrm{c}} \pm 12.3$ & $21.7 \%$ \\
\hline LSD value at 0.05 & 6.8 & & 6.6 \\
\hline
\end{tabular}

Mean with the same letter are not significantly different

Table (3): Relationship between phytochmical components of three watermelon cultivars leaves and population of Tetranychus urticae

\begin{tabular}{|c|c|c|c|c|c|c|c|c|c|}
\hline \multicolumn{8}{|c|}{ Phytochemical componds } & \multirow[b]{2}{*}{$\begin{array}{c}\text { Total } \\
\text { carotines } \\
\mathrm{g} / 100 \mathrm{~g}\end{array}$} & \multirow[b]{2}{*}{$\begin{array}{c}\text { Tannines } \\
\mathrm{g} / 100 \mathrm{~g}\end{array}$} \\
\hline cultivars & infestation & $\begin{array}{c}\text { Mean of } \\
T . \text { urticae } \\
\text { eggs }\end{array}$ & $\begin{array}{c}\text { Mean of } T \\
\text {.urticae } \\
\text { movable stage }\end{array}$ & $\begin{array}{l}\text { Total amino } \\
\text { acids } g / 100 \mathrm{~g}\end{array}$ & $\begin{array}{c}\text { Total free } \\
\text { amino acids } \\
\mathrm{g} / 100 \mathrm{~g}\end{array}$ & $\begin{array}{l}\text { Total phenolic } \\
\text { compounds } \\
\mathrm{g} / 100 \mathrm{~g}\end{array}$ & $\begin{array}{c}\text { Total } \\
\text { Alkaloids } \\
\mathrm{g} / 100 \mathrm{~g}\end{array}$ & & \\
\hline & peak & 74.20 & 86.16 & 29.26 & 6.34 & 2.70 & 0.22 & 10.22 & 1.71 \\
\hline \multirow[t]{3}{*}{ Shahd 2} & Late season & 55.10 & 84.13 & 19.00 & 5.51 & 2.45 & 0.23 & 8.27 & 1.54 \\
\hline & mean & 64.65 & 58.2 & & & & & & \\
\hline & peak & 86.38 & 97.16 & 29.63 & 6.13 & 2.67 & 0.24 & 12.65 & 1.87 \\
\hline \multirow[t]{3}{*}{ Galia 2} & Late season & 68.17 & 91.30 & 20.14 & 4.28 & 2.30 & 0.23 & 9.12 & 1.66 \\
\hline & mean & 77.3 & 94.3 & & & & & & \\
\hline & peak & 48.14 & 38.10 & 28.95 & 6.00 & 3.14 & 0.20 & 13.92 & 2.11 \\
\hline \multirow[t]{2}{*}{ Ananas france } & Late season & 23.10 & 31.15 & 18.23 & 5.65 & 3.56 & 2.16 & 11.54 & 1.92 \\
\hline & mean & 35.6 & 34.6 & & & & & & \\
\hline
\end{tabular}

$21.1 \%$ and for the second season (2013) it was Galia 2 , Ananas France and Shahd2 44.5, 34.8 and 20.7\%, respectively.

The mean numbers of T. urticae and infestation eggs percentages followed similar trend (table 2) during the same successive seasons. It could be arranged descendingly as follows: Galia2 (43.4 and 50\%), Shahd2 (33.9 and 35.4\%) and Ananas france (22.7 and $25.4 \%$ ) during the two seasons.

\section{Population dynamic of Tetranychus urticae on three muskmelon cultivars:}

Population dynamic of the two spotted spider mites T. urticae motile stages and eggs were recorded during winter seasons 2012 and 2013 from mid January up to the last week of April .During season 2012, the infestation of muskmelon cultivars Shahd2, Galia2 with motile stages $T$. urticae started from mid
January then gradually increased to reach its peak in the beginning of third week of April and in beginning of second week for Anans france. The number of motile stages of $T$. urticae /leaf for Ananas France 'Galia 2 and shahd 2 cultivars averaged 5.23, 9.2 and 7.35 in the beginning of infestation, respectively then increased to $41,97.16$ and 86.16 in the peak of infestation, respectively (Fig.1), and in the beginning of infestation of the previous muskmelon cultivars with motile stages of T. urticae during season 2013 averaged 6.25 ' 10.35 and 8 for Ananas fenace, Galia 2 and Shahd2, respectively, and increased to 39.7 in the third week of march for Ananas france and reached 100.3 and 68.43 in the second week of April, respectively (Fig2). The numbers of eggs/leaf was $7.13,11.18$ and 8.3 in the beginning of season 2012 for Ananas france, Galia2 and shahd2, respectively, and increased to reach its peak to 48.14 and 86.38 in the beginning of April for Ananas france, Galia2, 
respectively and 74.20 for shahd2 (Fig3). In season 2013 the numbers of eggs/leaf was 6.98, 13.50 and 9.15 in the beginning of season, and reached its peak 49.3478 .25 in the third week of March for Ananas france and Galia2, respectively and 75.25 in the beginning of April (Fig4).

One of the most important factors which play a role in the susceptibility of muskmelon cultivars to $T$. urticae infestation is leaf phytochemical components. Obtained data in table 3 indicated negative relationship occurring between motile mite infestation levels and total Alkloids; while no correlation for eggs with all components as shown in table 3 . These results are in disagreement with those obtained by EL-Saiedy et al., 2011 but in agreement with Edelstain et al. (2000), Cactagnoli et al. (2003), Maklad (2004) and Abdallah et al (2009).

\section{REFERENCES}

Abdallah, A. A.; El-Saiedy, E. M. A.; Sholla, Saiwa, M. E. and El-Fatih, Monira, M. 2009. Field and Labortory studies to evaluate three squash cultivars for their relative susceptibility to spider mite Tetranychus urticae Koch and three sucking insect species. Minufiya, Agric. Res., 34(5):1913-1926.

Burn, E. R. 1971. Method for estimation of tannin in grain Sorghum Argon, 511pp.

Castagnoli, M.; Liguori, M.; Simoni, S.; Marinari, S. and Soressi, G. P. 2003. Tomato stransgenic lines and Tetranycus urticae: changes in plant suitability and susceptibility. Exp. App. Acarol., 31(3-4): 177-189.

Edelstain, M.; Tadmor, Y.; Abo-Moch, F.; Karchi, Z. and Mansour, F. 2000. The potential of
Lagenaria rootstoch to confer resistance to the carmine spider mite, Tetranychus cinnabarinus (Acari: Tetanychidae). Bull. Entomol. Res., 90:113-117.

El-Saiedy, E. M. A.; Afifi, A. M.; Fatma, S. Ali and Ahmed, M. M. 2011.Susceptibility of four watermelon cultivars to infestation with Tetranychus urticae Koch. Acarine, 5(1): 23-28.

Etsushiro, D.; Daisuke, S. and Eruyoshi, M. 1981. Modified colormetric ninhydrine methods for peptidase assay. Anal. Biochem., 118:173-184.

Farrag, A. M. I.; Wahba, M. L. and Abdel-Hafez, M. A. 1984. Effect of planting date on the population fluctuations of Tetranychus urticae on some cucurbitaceous plants at Qualyobia Province. Agri. Res., 60 (1): 107-117.

Holden, M. 1965. Chlorophylls: In chemistry and biochemistry of plant pigment. Ed., Goodwin, T. W.,PP.462-488. Academic press, London.

Kousik, C. S.; Shepard, B. M.; Hassell, R.; Levi, A. and Simmons, A. M. 2007. Potential sources of resistance to broad mites (Polyphagotarsonemus latus) in watermelon germplasm. Hort. Science, 42 (7): 1539-1544.

Makled, A. M. 2004. Ecological studies on some insects and animal pests infesting certain vegetable crop under protected cultivation and their control. M.Sc. Thesis. Fac. of Agric. AlAzhar Univ., 321pp.

Meda, A.; Lamien, C. E.; Romito, M.; Millogo, J. and Nacoulma, O. G. 2005. Determination of total phenolic, flavonoid and proline contents in Burkina Fasa honey, as well as their radical scavenging activity. Food Chemistry,91: 571-577.

Sabri, N. N.; El-Masry, S. and Khafaey, S. M. 1973. Phytochemical investigation of Hyoscyamus desertorurn. Planta Medica, 23:49. 